\title{
Urbanisme, arquitectura i patrimoni a la Borriana del canvi de millenni
}

\author{
Ivan Cabrera i Fausto (ivcabfau@mes.upv.es) \\ Ernesto Fenollosa Forner (efenollo@mes.upv.es) \\ Universitat Politècnica de València
}

\section{L'ocupació del territori}

Borriana ha vist com l'activitat urbanística i la construcció arquitectònica han cobrat un protagonisme sorprenent, especialment els darrers quinze anys. De manera semblant a molts altres indrets de l'Estat espanyol, durant el període de la bombolla immobiliària aquest sector econòmic va guanyar un pes específic mai no vist abans en molts àmbits. I també ara, en plena crisi, les conseqüències es deixen sentir d'una manera més que notable. Afecten no només l'economia local, sinó també el paisatge urbà i natural que hem heretat d'aquests anys de bogeria.

Es compleixen vint-i-cinc anys de les contribucions que molts autors com ara Katia Torrent, Enric Pla, Blas Català i molts altres van fer als capítols dels llibres de Burriana en su historia ${ }^{1}$ en aquesta matèria i altres afins. Hem utilitzat els seus escrits com a punt de partida per a dirigir la nostra atenció cap a l'urbanisme, l'arquitectura i el patrimoni de Borriana durant el darrer quart del segle passat. Potser això ens permeta entendre el moment actual i també millorar el futur.

Des de la fundació, la ciutat va mantenir una intensíssima relació amb el camp, extremadament fèrtil, que l'envoltava. ${ }^{2}$ Les possibilitats agrícoles que aquest medi geogràfic engendra (Torrent i Pla, 1987: 317) expliquen l'àmplia colonització i humanització, verificable arran d'un gran nombre de camins, alqueries, casetes d'eines, corrals, pous, séquies, ermites i, fins i tot, torres i palaus que, en millors o pitjors condicions, han arribat als nostres dies. ${ }^{3}$ Però, durant el segle xx, els mètodes moderns d'explotació agrària i la difusió de l'ús del vehicle van fer innecessària la presència dels llauradors a la vora de les terres que conreaven. Després de molts anys densament ocupats (Mesado, 1991: 187) els camps de Borriana es van despoblar i els habitants es van traslladar a la ciutat i a unes altres aglomeracions menors. Malauradament, aquesta migració s'ha traduït en una creixent distància mental entre els veïns de la ciutat i els camps que l'abracen. Errada especialment sagnant en el cas de moltíssims partícips en la planificació urbanística del municipi que han tractat el nostre terme com un full en blanc, sobre el qual escriure de qualsevol manera i tant com es volgués, sense la més mínima sensibilitat a les inèrcies i el caràcter del territori que manipulaven.

\footnotetext{
${ }^{1}$ Burriana en su historia va ser publicat en 1987 i Burriana en su historia II va veure la llum en 1991.

${ }^{2}$ En l'article «Evolución urbana», K. Torrent i E. Pla expliquen com, des dels inicis, el nucli urbà de Borriana ha estat l'element aglutinador d'un entorn agrari tan potent, que fins i tot, sovint es donava l'esquena a la mar. ${ }^{3} \mathrm{~N}$. Mesado defineix, en Nuestro campo y su patrimonio cultural, el terme de Borriana com un llençol verd on s'encasten els elements de l'arquitectura rural, amb especial densitat pel que fa a les alqueries.
} 
Els primers documents urbanístics de què tenim notícia són de 1847, quan s'encomana l'alçament d'un plànol geomètric del nucli urbà, arran del ràpid creixement de la població. Però, les primeres eines de planejament no arribaran fins al 1896, quan l'Ajuntament aprova el plànol de noves alineacions elaborades per l'arquitecte municipal d'aleshores, Francisco Tomás Traver. Tot i això, la primera documentació escrita encara trigarà més de vint anys a arribar. Les primeres ordenances municipals es redacten en 19194 (Català, 1991: 478). En 1935, el mai no suficientment valorat arquitecte municipal, Enrique Pecourt Betés, elabora el Plano general de Burriana, que a més a més de la delimitació del nucli urbà, preveu una zona d'eixample i una incipient zona industrial, però la inclusió dels poblats marítims en el planejament no arribarà fins el 1958. Tradicionalment, i fins a l'aprovació del Pla General d'Ordenació Urbana de 1964, les edificacions sempre anaven per davant del planejament. Però, a partir d'aqueixa data la tendència canvia i el planejament comença a anar per davant de les iniciatives de la construcció i de les veritables necessitats del municipi. Aquesta nova dinàmica s'accentua quan, en 1980, la corporació municipal tria la tercera i més ambiciosa de les propostes presentades per l'empresa Prodein a la qual havia estat adjudicada la revisió del Pla General (Català, 1991: 478).

La bombolla immobiliària arriba a Borriana en plena explotació del Pla General d'Ordenació Urbana de 1995, elaborat per l'arquitecte Alejandro Escribano. Aquest planejament, tot i ser de nou molt ambiciós, aviat serà considerat insuficient pels valedors de la inexorable eternitat de l'auge del mercat immobiliari. El seu desig d'incorporar al procés urbanitzador terrenys inicialment no previstos en el Pla General serà possible gràcies a la Llei reguladora de l'activitat urbanística de la Comunitat Valenciana, aprovada en novembre de 1994. Aquesta Llei, suposadament concebuda per a abaratir el preu del sòl, disposava, en l'articulat, de mecanismes que permetien proposar nous desenvolupaments urbanístics. I el que és més greu, possibilitaven que el fet d'urbanitzar es convertira en un negoci lucratiu en si, sovint desvinculat de les necessitats reals de creixement del poble o del desig dels propietaris afectats. ${ }^{5}$ Finalment i perillosament desconnectada de les necessitats de la construcció arquitectònica, Borriana assistirà a la més important expansió urbanística de la història. En un termini inferior a deu anys, els preus dels terrenys, abans i després de la urbanització, experimentaran unes pujades aborronadores. Aquestes plusvàlues, unides a les dificultats que des d'anys enrere arrossegaven les explotacions de cítrics, posicionaran la majoria de la població i els seus polítics a favor d'aquesta nova font de prosperitat que llavors molts pocs es van atrevir a qüestionar.

Quant d'eixample necessitàvem realment? La figura 1 ens mostra, en el terç superior, l'evolució de la població de Borriana des de principis del segle xv fins a l'any $2012 .{ }^{6}$ En el terç central trobem l'evolució de la superfície urbana, on només s'han inclòs les zones

\footnotetext{
${ }^{4}$ El Proyecto de ordenanzas municipales del Magnífico Ayuntamiento de la Ciudad de Burriana y Reglamentos para el régimen interior del mismo, de 1919, i les Normas de policía y sanitarias establien una regulació concreta del règim constructiu, es regulaven les llicències d'obres, alineacions i rasants, etc. (Català, 1991: 478). ${ }^{5}$ Els guanys que les empreses impulsores dels nous desenvolupaments urbanístics han obtingut han estat de molts tipus, des dels honoraris professionals per les gestions, als beneficis industrials per les obres d'urbanització i l'obtenció de nombrosos solars a preus finals significativament inferiors als del mercat.

${ }^{6}$ Els valors de població de 1404, 1609 i 1797 s'han obtingut de l'article de K. Torrent i E. Pla «Evolución de la población en la edad moderna», dins de Burriana en su historia II. La resta de valors s'ha obtingut del web de l'Institut Nacional d'Estadística.
} 


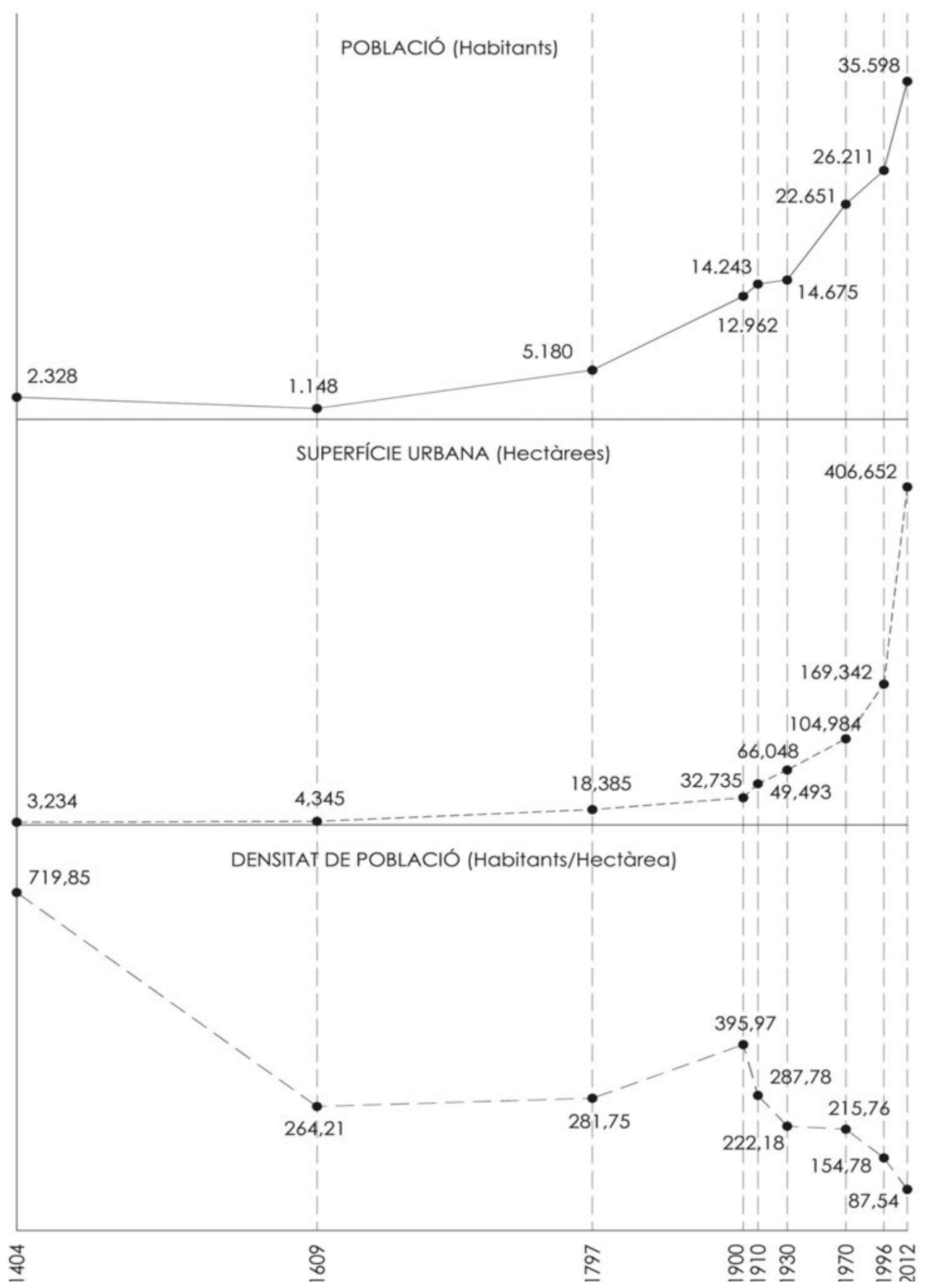

Figura 1. Evolució de població, superfície urbana i densitat de població. 
realment consolidades; és a dir, on l'edificabilitat està total o quasi totalment executada. El terç inferior recull l'evolució cronològica de la densitat de població i mostra clarament com el creixement de la superfície urbana ha estat molt més ràpid que el de la població amb densitats decreixents que, en el cas del termini de vigència de l'actual Pla General d'Ordenació Urbana, s'han reduït gairebé a la meitat. Els motius d'aquesta davallada tan gran en la densitat de població per hectàrea s'estructuren bàsicament en tres grups.

En primer lloc, la millora en les condicions de vida de la població s'ha traduït, entre altres, en una millora dels estàndards dels habitatges. Arran d'una millora en la seua situació econòmica personal, molts borrianencs han adquirit un nou habitatge, i l'anterior ha romàs buit en l'actualitat amb relativa freqüència. La millora dels estàndards també s'ha materialitzat en la popularització de tipologies constructives, com ara els habitatges aïllats, aparellats o en filera que consumeixen molta més superfície per habitant que no l'edificació tancada o en alçada. ${ }^{7}$

En segon lloc, s'han incorporat a la zona considerada com a urbana, nombroses zones d'habitatges del districte marítim i zones industrials que havien estat edificades, al seu dia, sense cap tipus de planificació i que sovint no disposaven dels serveis urbanístics més elementals, com ara l'accés rodat en condicions dignes o el clavegueram. És ben just assenyalar, en aquest punt, que la urbanització d'aquestes zones irregularment colonitzades ha estat un dels grans beneficis que la ciutat ha tret d'aquests anys on l'activitat urbanística era un negoci productiu i els preus pujaven a tot arreu. Fins i tot indrets que històricament havien suscitat poc d'interès per a la població van trobar empreses decidides a desenvoluparlos. Aquest és el cas del barri de Llombai, on els antics descampats existents entre la ronda de Pere IV i l'avinguda de Jaume I constitueixen avui un dels barris més joves i dignes de Borriana. Malauradament, la vertiginosa empenta que va caracteritzar els anys de la bombolla va perdre tota la força abans que els beneficis s'estengueren al barri veí de l'Hereu o a altres buits amb característiques semblants, ${ }^{8}$ el rebliment dels quals hauria suposat un creixement de la ciutat acord amb la tradicional geometria concèntrica i que el PGOU sempre havia intentat preservar i potenciar.

En tercer lloc i finalment, moltes promocions no s'han venut al ritme que calia esperar. Són nombroses les obres que han quedat aturades per falta de perspectives de venda i també els edificis de nova creació amb un percentatge d'habitatges buits significatiu.

La figura 2 reflecteix l'evolució de la superfície urbana de Borriana des del segle XV fins a l'actualitat. La superfície urbanitzada fins a 2012 inclou només les zones majoritàriament construïdes. Si sostraiem mentalment les zones residencials marítimes i industrials prèviament consolidades i que han estat urbanitzades durant aquest període, observarem com la superfície urbanitzada estrictament novella suposa un creixement molt semblant al d'altres etapes del segle xx amb augments demogràfics semblants. ${ }^{9}$ Així

\footnotetext{
${ }^{7}$ A partir dels anys seixanta, l'extensió del poble es produeix més en alçada que en superfície (Torrent i Pla, 1987: 332).

${ }^{8}$ El nou barri d'Artana té les obres d'urbanització acabades, però es troba pràcticament desert. El nou barri d'Hortolans té les obres d'urbanització interrompudes. Les propostes per als barris del Palau i del Forn de la Calç, a la vora nord del riu Anna, mai no van superar la fase documental.

${ }^{9}$ El parc industrial de Carabona escapa a aquestes consideracions. Tot i que l'ocupació actual és d'aproximadament un 50\%, té l'honor de ser l'operació de gran envergadura més reeixida d'aquest període, privilegi que, potser, en un futur li prenga el barri de Novenes.
} 


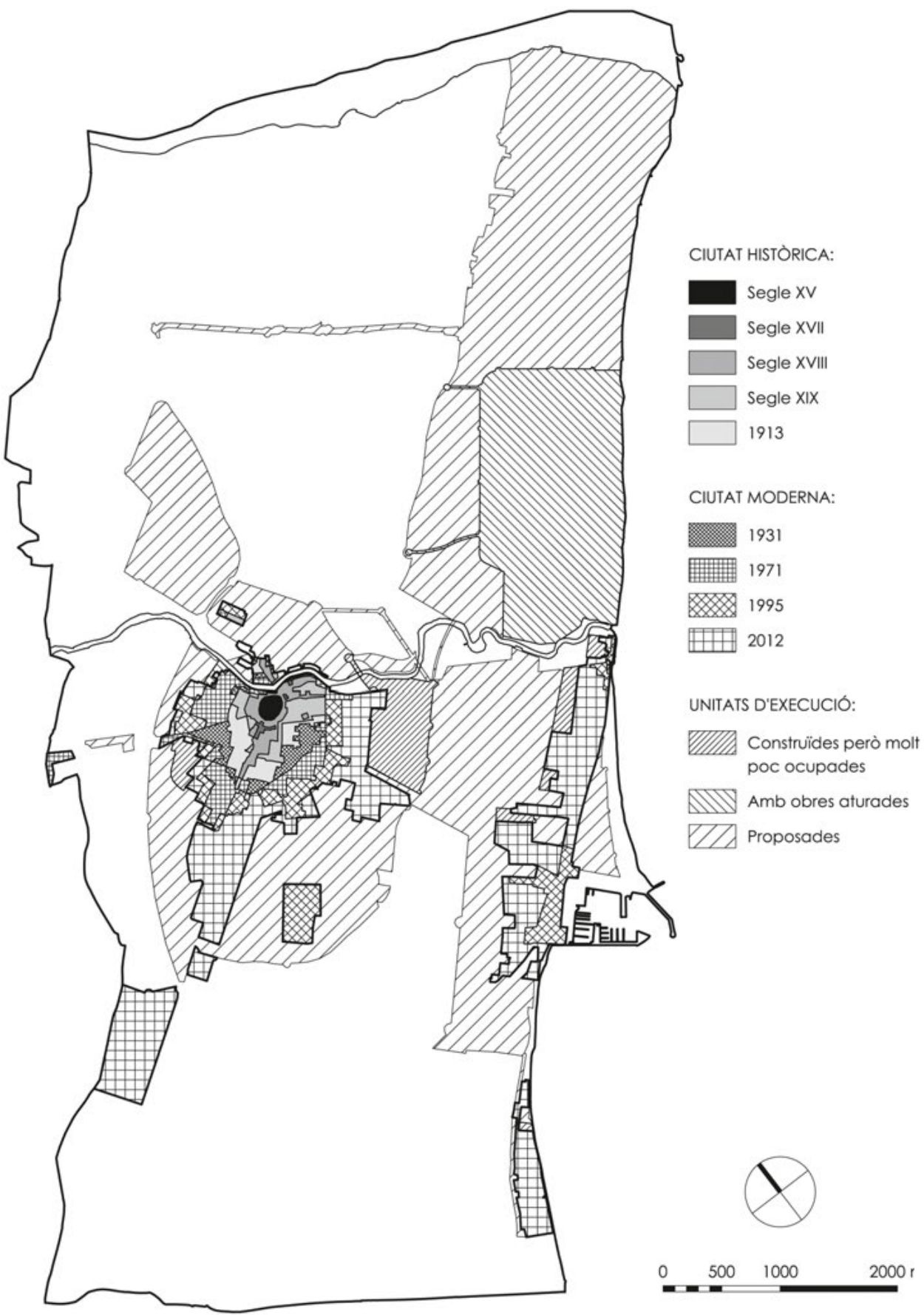

Figura 2. Evolució de la superfície urbana al terme municipal de Borriana des del segle xv a l'actualitat. 
doncs, l'escassa ocupació actual dels barris d'Artana i Novenes, tot i l'especificitat de les tipologies d'edificació que contemplen, ${ }^{10}$ pareix que no respon exclusivament a la crisi actual, sinó també a la momentània absència d'una necessitat real d'expansió de la ciutat. Amb aquests raonaments, si és dubtosa la necessitat de les zones on les obres d'urbanització han quedat interrompudes per falta d'inversió, òbviament, el que mai no va fer falta és l'allau de propostes que han quedat en fase estrictament documental o que mai no van rebre l'interès de cap empresa. Aquestes zones representen un total d'1.121,583 hectàrees, xifra especialment escandalosa si es compara amb les 406,652 hectàrees de la zona urbana consolidada i si, a més a més, es prenen en consideració les 65,377 hectàrees de zones que, tot i estar construïdes, estan poc ocupades i les 258,153 hectàrees de zones amb les obres d'urbanització aturades.

Els defensors d'urbanitzar el 39,55\% del terme municipal argumentaven que la demanda mai no arribaria si no es generava l'oferta d'habitatges, de serveis i de sòl industrial. Però moltíssims municipis amb característiques geogràfiques semblants a Borriana oferien un producte gairebé idèntic. L'arribada simultània de l'esclafit de la bombolla a escala nacional i de la crisi financera d'àmbit internacional aviat va acabar amb els somnis dels inversors i d'un sector de la població i els seus representants polítics. Aquestes propostes que ja llavors semblaven excessives han deixat avui l'administració pública certament sobrecarregada en l'acabament o resolució dels expedients, un mar d'empreses i entitats financeres fallides i, el que és més greu, un nombrós col·lectiu de propietaris captius del pagament d'avals i tributs de tot tipus.

Com volíem créixer i com hem crescut? El Pla General d'Ordenació Urbana de 1995 preservava el caràcter centrípet i concèntric de la ciutat i la mantenia dins d'un segon cinturó de rondes amb centre a la cruïlla del Raval amb l'Escorredor, i amb un ús eminentment residencial. Recollia la clara voluntat de regularitzar la situació de tot el districte marítim des del camí del Marge a la desembocadura del riu Anna, s'urbanitzava una franja de gruix variable en funció de l'interès de la zona per a l'ús turístic i de segona residència. Aquest esquema tan simple es veia completat per la urbanització de la carretera del Port i la urbanització de les preexistències industrials situades sobre la carretera de Nules i el camí de Llombai. L'explotació normal del Pla General aviat es va veure sacsejada per dues arribades inesperades. D'una banda, la construcció de la CV-18 va alterar la disposició del segon cinturó de ronda, es van haver de modificar els trams propers a la variant per a aprofitar la nova infraestructura. I, d'altra banda, l'aparició creixent d'iniciatives privades per a urbanitzar terrenys inicialment no previstos en el Pla General distorsionava el disseny original d'Alejandro Escribano. L'èxit de les primeres operacions i la posterior escalada dels preus van dibuixar un horitzó de gran ciutat. Però, els macroelements que l'haurien d'articular no van ser dissenyats des del principi i apareixien a mesura que més i més metres quadrats s'incorporaven a les previsions municipals. Les connexions viàries a gran escala van ser implementades mitjançant negociacions amb els promotors i tècnics de propostes quan ja estaven iniciades. Així i tot, es va aconseguir la materialització d'elements tan

\footnotetext{
${ }^{10}$ El barri d'Artana i gairebé dos terços del barri de Novenes estan previstos per a construir-hi habitatges en filera, aparellats i aïllats. Aquesta tipologia, amb important presència al districte marítim, és actualment bastant escassa a la ciutat i durant les tres darreres dècades del segle xx va esdevenir molt popular.
} 
dignes com les avingudes de París i de Londres o l'intermitent Vicent Cañada Blanch. ${ }^{11}$ Paral-lelament, la ubicació de zones verdes va quedar a criteri dels tècnics redactors de les propostes amb un excessiu protagonisme de les caríssimes d'executar i baratíssimes de mantindre zones pavimentades i una escassesa notable d'arbres i plantes. ${ }^{12}$

Notablement condicionada per aquestes circumstàncies, Borriana creixia. La colonització del territori fins al segon cinturó de ronda ha estat molt variable. L'atractiu que durant els anys seixanta, setanta i vuitanta va tindre el camí d'Onda es va traslladar a la part baixa de la ciutat, el barri de Calatrava va experimentar un notable auge, germen de la posterior aparició del nou barri de Novenes, més enllà del segon cinturó de ronda. Mentrestant, al barri d'Hortolans amb prou feines ha crescut alguna illa i les dues unitats que el completarien tenen les obres aturades o han quedat en fase documental. A l'oest, el barri d'Artana només ha finalitzat les obres d'una de les unitats, mentre que l'altra no ha superat la fase documental a causa, tant de la fallida de l'empresa adjudicatària, com de l'escàs interès que les parcel·les de la zona han suscitat, no s'hi ha edificat ni una sola construcció de nova planta. Tot i haver-ne millorat la imatge durant els últims anys, el barri de la Bosca és encara un indret poc atractiu per a la inversió i tampoc ha completat una potencial zona d'eixample fins al segon cinturó de ronda que, en aquesta zona, ni tan sols s'ha arribat a materialitzar amb els importants problemes de trànsit i la incongruència que això suposa. Al sud, el barri de l'Ecce Homo era l'únic que ja havia arribat a la segona ronda abans de la redacció del nou Pla General. Fins i tot habitatges unifamiliars aïllats ja s'havien situat a l'altra banda de l'avinguda de Jaume $\mathrm{I},{ }^{13}$ procés que ha continuat durant tots aquests anys fins a gairebé omplir tot el vial. Tal com s'ha referit abans, a l'esquerra, el barri de Llombai ha experimentat un dels creixements i regeneracions més notables dels últims vint anys. L'agradable secció de l'avinguda homònima, la qualitat arquitectònica mitjana acceptable dels edificis i la joventut de la majoria dels nous inquilins, el converteixen en una zona magnífica que s'ha desfet totalment del caire certament marginal que la caracteritzava vint anys enrere.

Malauradament, l'impuls regenerador no va arribar a temps al barri veí de l'Hereu, al voltant del renovat accés des de Nules. Tot i que les obres d'urbanització estan acabades l'ocupació de l'Hereu és molt baixa. Finalment, al nord, la barrera més psicològica que física que el riu sempre ha suposat per als borrianencs (Torrent i Pla, 1987: 315) no ha pogut ser enderrocada. Sembla que el raval de Tortosa haurà d'esperar encara més, perquè les propostes presentades per al sanejament i per a la creació dels barris del Palau i del Forn de la Calç no han superat la fase documental.

El districte marítim ha estat, possiblement, el gran beneficiat de l'ímpetu urbanitzador d'aquests anys. Des de la Serratella fins al Grau, barris sencers que s'havien edificat sense

\footnotetext{
${ }^{11}$ Tot i disposar d'un disseny unificat, les avingudes de Vicente Cañada Blanch i la continuació al sud amb l'avinguda dels Descobridors encara estan desconnectades en tres trams.

${ }^{12}$ El parc lineal de ribera que es materialitza en l'actualitat per a connectar la ciutat amb el Clot de la Mare de Déu, declarat Paratge Natural Municipal, el 8 de febrer de 2002, constitueix, possiblement, l'única planificació a gran escala de zones verdes i parcs al municipi de Borriana.

${ }^{13}$ L'avinguda de Jaume I era l'únic tram del segon cinturó de ronda construït abans de l'aprovació del PGOU de 1995. No disposava de jardí central i aquesta circumstància ha permès, malauradament, que els carrils centrals hagen estat convertits en aparcaments en bateria, amb els consegüents deslluïments i problemes per al trànsit de vehicles de dimensió considerable.
} 


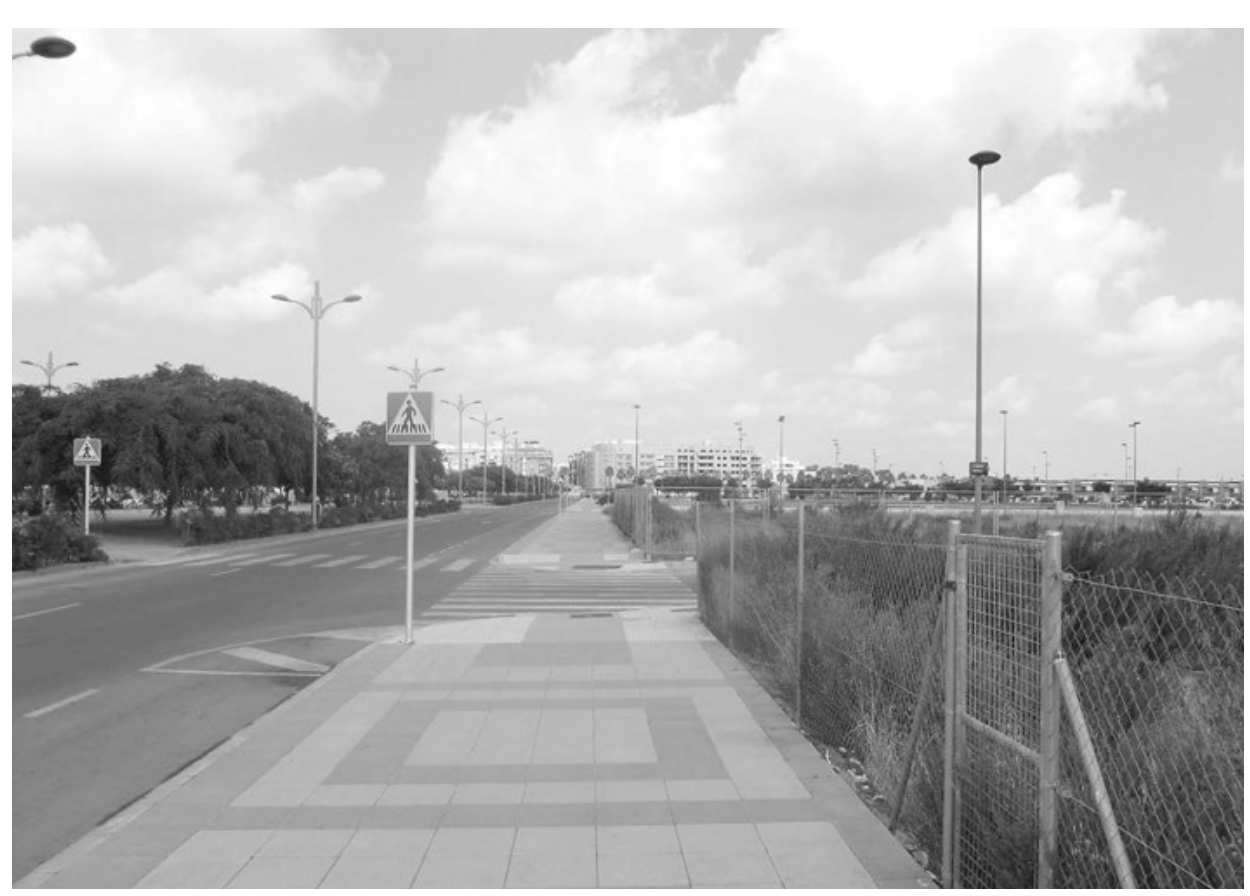

Avinguda de Londres al barri de Novenes (Foto: I. Cabrera).

cap tipus de planificació ni serveis s'han vist convenientment urbanitzats, no sempre amb el grat dels veïns, sovint molestos per haver de cedir els terrenys necessaris per a eixamplar els carrers i les zones dotacionals i pel pagament de les corresponents quotes d'urbanització. A més a més, les zones més atractives, com ara certs buits a primera línia de mar a la Serratella, han augmentat l'extensió dels barris de la Pedrera, el Port, la Malva-rosa i el Grau amb la disposició de nous carrers cap al poble. Tret de l'important creixement del Grau, la majoria d'aquestes ampliacions estaven previstes al PGOU de 1995. Tanmateix, les previsions d'Alejandro Escribano, pel que fa a sòl industrial i que es reduïen a la urbanització de les zones preexistents al voltant de la carretera de Nules i del camí Llombai, es van revelar insuficients. Així doncs, el parc empresarial de Carabona ha tingut una acollida excel·lent al municipi; però, el fet d'estar ocupat només al 50\% posa de manifest que els múltiples parcs industrials que es van suggerir al voltant del camí vell de València i de la carretera de Vila-real eren absolutament innecessaris i només constituïen un negoci pròsper per aquells que gestionaren i materialitzaren el procés urbanitzador.

Afortunadament per a uns i malauradament per a altres, també han quedat només proposats o embossats en fase documental les propostes per la segona fase de Sant Gregori, Santa Bàrbara, Pedrera-Port, Jardins de la Malva-rosa i molts altres amb noms menys mediàtics que, tal com reflecteix la figura 2, gairebé quadruplicaven l'extensió urbana a la qual finalment ha arribat Borriana. La paralització ha estat un drama per a molts implicats. Però, a la vista del tracte que ha rebut l'entorn natural durant el disseny i l'execució de 
les obres que sí que han tirat endavant, cal reflexionar al voltant de la conveniència de protegir-lo, ja que en tots els casos han suposat una desforestació massiva i irreflexiva i la devastació completa del patrimoni rural edificat. ${ }^{14}$

Pel que fa a la qualitat del disseny de les urbanitzacions, la casuística és tan extensa que trobem exemples de tot tipus. La idea de ciutat i la qualitat de les seccions dels carrers del nou barri de Novenes contrasta amb el creixement amorf i irrellevant del Grau o amb la col-lecció de places dures absolutament deixades caure de les unitats d'execució de la Serratella. El subtil i quasi britànic disseny del barri d'Artana contrasta amb la monotonia de les quadrícules d'altres indrets. Finalment, la plaça de les Caravel-les constitueix un dels escassíssims exemples de zona verda pública digna, en un fortíssim contrast amb la inhabitable plaça de l'Hereu o els terribles jardins d'Espanya, que no tenen cap virtut més enllà de ser un espai públic i obert.

\section{L'arquitectura}

De manera semblant com va succeir a partir de 1858 amb l'auge del comerç de la taronja i la riquesa que va propiciar (Goerlich, 1987: 347), l'auge de la construcció podria haver millorat encara més l'aspecte de la ciutat. Però, segle i mig després, la sort de Borriana ha estat molt més irregular.

L'any 1994 s'inaugurava el nou edifici de l'ajuntament. Amb un solar lleugerament més gran que el del vell edifici, mercè a la compra d'algunes cases annexes, el veïnatge amb l'històric edifici del Salvador i el fort paper representatiu dotaven al projecte d'una complexitat significativa. L'edifici actual, amb façana clarament inspirada en la de l'ajuntament de Palma de Mallorca, ${ }^{15}$ va ser rebut gratament per la majoria de la població, que va valorar-ne especialment la claredat en la distribució de l'espai interior i la consegüent facilitat en l'accés als diferents serveis oferts.

Dos anys abans, en 1992, s'havia inaugurat l'edifici de l'Escola de la Mar, al començament de l'avinguda de la Mediterrània. Amb projecte de José Luis $\operatorname{Ros}^{16}$ i amb referències a nombrosos exemples de l'arquitectura de Le Corbusier, és un edifici brillant i pràctic que, tot i privar de les vistes del port als veïns dels pisos inferiors d'aquesta zona de l'avinguda, ha dotat el barri de vida i caràcter.

En 1997, el famós estudi d'Albert Vilaplana i Helio Piñón redactava el projecte per la nova Casa de la Música a les immediacions de l'església de Sant Blai. Presentada la maqueta de l'edifici al gran públic, el projecte no va obtindre el vistiplau dels tècnics de patrimoni que consideraven que l'alçada i voluminositat de la caixa d'escena desmereixien el cimbori del temple veí. Malauradament, no es va valorar la gran qualitat del projecte i l'operació de sanejament del barri que hauria suposat, amb especial mèrit de la nova façana

\footnotetext{
${ }^{14}$ És paradoxal que durant les obres d'urbanització de moltes unitats s'han arrancat els arbres i s'ha enderrocat el patrimoni rural en zones previstes com a parcs i jardins i que han acabat dotades d'un enjardinament molt més escàs i deficient.

${ }^{15}$ L'esquema compositiu de la façana de l'ajuntament de Palma de Mallorca i, conseqüentment, de la de l'ajuntament de Borriana està inspirat en la del palau Farnese de Roma que, amb projecte original d'Antonio da Sangallo el Jove, va ser desenvolupat bàsicament per Miquel Àngel.

${ }^{16}$ José Luis Ros Andreu és catedràtic d'universitat del Departament de Projectes Arquitectònics de l'UPV.
} 
recaient al riu. El projecte va acabar en un calaix i el govern municipal va dirigir llavors la seua atenció al teatre Payá. El magnífic edifici, obra d'Enrique Pecourt, ${ }^{17}$ era propietat de la família Payá que començava a qüestionar-ne la viabilitat de l'explotació com a cinema. Després de la compra de l'immoble, les distintes regidories de l'Ajuntament li van donar ús com a teatre i sala d'actes, tot i que l'estat de conservació requeria cada vegada amb més urgència la restauració. L'any 2010 l'Ajuntament decidia invertir 4,8 milions d'euros del Pla Confiança de la Generalitat Valenciana en un pretès condicionament que derivaria en la quasi pràctica destrucció de l'edifici de Pecourt i la construcció d'un de nou. Corria així el teatre Payà la mateixa sort que el teatre Principal o el cine Viciana, però afortunadament sense ser substituït, en aquest cas, per un edifici d'habitatges.

Tot i l'alçament d'alguns edificis públics amb una arquitectura absolutament intranscendent, com ara la del centre de salut «Burriana», el centre sanitari integrat «Burriana II» o el Centre Especial d'Atenció als Majors i l'Escola Municipal de les Arts com a exemples, els plans d'estímul de l'economia del govern central i de l'autonòmic van proporcionar a la ciutat altres edificis de gran qualitat. L'exemple més notori és el nou pavelló poliesportiu de la Bosca, obra dels arquitectes catalans Josep Maria Gordi, Jordi Jané, Francesc Puig i Anna Fumadó. ${ }^{18}$ El projecte, desenvolupat en un temps rècord en 2010 per a arribar a temps als terminis imposats pel Pla E., és, molt possiblement, el millor edifici que s'ha construït a Borriana en el darrer quart de segle. A més a més de servir de llar dels equips de bàsquet de la ciutat, ha millorat els serveis de l'annex i preexistent poliesportiu municipal i ha suposat una ventada d'aire fresc per al barri de la Bosca. Les façanes, envidrades en groc, verd i blau a nivell del carrer, permeten observar des de les voreres l'interior de l'edifici, mentre que la torre d'accés al camp de futbol sala elevat constitueix un final de perspectiva magnífic per al carrer de la Bosca.

També arran de la disponibilitat econòmica mercè al Pla E., l'Ajuntament va encarregar a l'estudi Vint-i-nou Arquitectura ${ }^{19}$ la nova caserna de la policia local. Tot i haver de respectar i reutilitzar l'estructura de l'antic edifici dels bombers situat al cantó del camí de la Cossa i l'avinguda del Setze de Juliol, l'edifici presenta unes façanes impecables i una distribució interior clara i funcional. També de gran qualitat és la nova sala d'assajos de la Banda Filharmònica Borrianenca, situada al pati del col·legi Hortolans, situació més aviat amagada i decebedora per a un edifici tan ben concebut. Obra de l'arquitecte borrianenc Joaquín Albert, en 2010, la construcció va ser possible mercè a la dotació econòmica assignada al municipi en el Pla Confiança, de la Generalitat Valenciana.

\footnotetext{
${ }^{17}$ Enrique Pecourt Betés va ser un dels arquitectes valencians més importants de la història i un dels pares del nostre art decó i del nostre racionalisme. Després d'obtindre el títol a l'Escola d'Arquitectura de Barcelona, en 1930, va ocupar la plaça d'arquitecte municipal de Borriana. Allí va ser l'autor d'edificis tan importants com l'enderrocat teatre Payà, el Mercat Central, els edificis d'habitatges número 2 del carrer de la Saleta i número 2 del Barranquet o les escoles de Santa Bàrbara.

${ }^{18}$ Josep Maria Gordi i Jordi Jané són socis de l'estudi Aquidos Arquitectes, juntament amb el llavors enginyer i ara arquitecte borrianenc, Miguel Marco. Francesc Puig és professor associat de Projectes a l'Escola d'Arquitectura de La Salle de la Universitat Ramon Llull, de Barcelona.

${ }^{19}$ L'estudi Vint-i-nou Arquitectura està compost pel borrianenc Héctor Lozano i el xilxer Víctor Alcañiz, ambdós titulats a l'Escola Tècnica Superior d'Arquitectura de la Universitat Politècnica de València.
} 


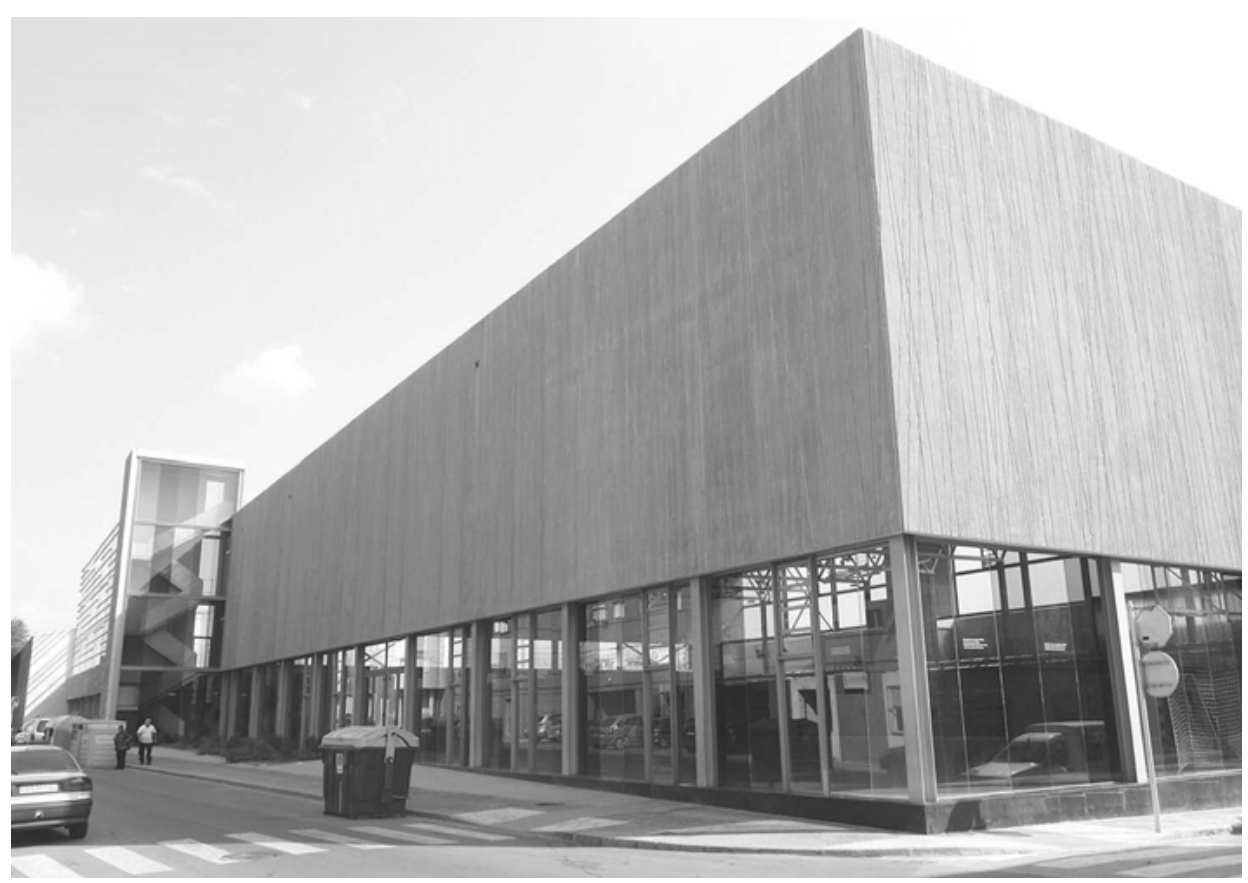

Nou pavelló poliesportiu de la Bosca, vist des del carrer homònim (Foto: I. Cabrera).

A l'hora de valorar la qualitat de l'arquitectura residencial resulta determinant establir una clara diferenciació entre els habitatges, normalment unifamiliars, promoguts per a ús propi i les grans promocions per a venda. Els primers sempre presenten una major probabilitat de trobar un propietari preocupat per alguna cosa més que la màxima economia. A finals dels anys vuitanta i principis dels noranta, l'arquitectura residencial unifamiliar a Borriana era, amb excessiva frequiència, tremendament conservadora i massa inclinada a llenguatges clàssics que alguns propietaris entenien com a sinònim de qualitat i lluïment. La construcció de l'habitatge unifamiliar situat al número 13 de l'avinguda de Jaume I va suposar un punt d'inflexió en aquesta manera de pensar i va obrir al gran públic el gust per una arquitectura més contemporània i desitjosa d'explorar les possibilitats dels nous materials i les noves maneres de viure. Projectat a meitat dels anys noranta pels arquitectes valencians Francisco José Reyes i José Luis Tolbaños, l'estructura de formigó, calculada pel també arquitecte Adolfo Alonso, ${ }^{20}$ permet uns jocs volumètrics i una riquesa espacial absolutament nous fins al moment. Després d'aquest projecte, la quantitat i la qualitat dels habitatges unifamiliars a Borriana han millorat de manera significativa. Per a comprovar-ho hi ha prou en fer una passejada pels nostres carrers, una especial densitat de bons exemples es troba als barris del Grau, la Malva-rosa i a les parcel-les pioneres del barri de Novenes.

\footnotetext{
${ }^{20}$ Adolfo Alonso Durà és professor titular d'universitat del Departament de Mecànica dels Medis Continus i Teoria d'Estructures de la Universitat Politècnica de València. És, a més a més, un famós calculista i entre els seus clients trobem l'arquitecte Daniel Libeskind.
} 


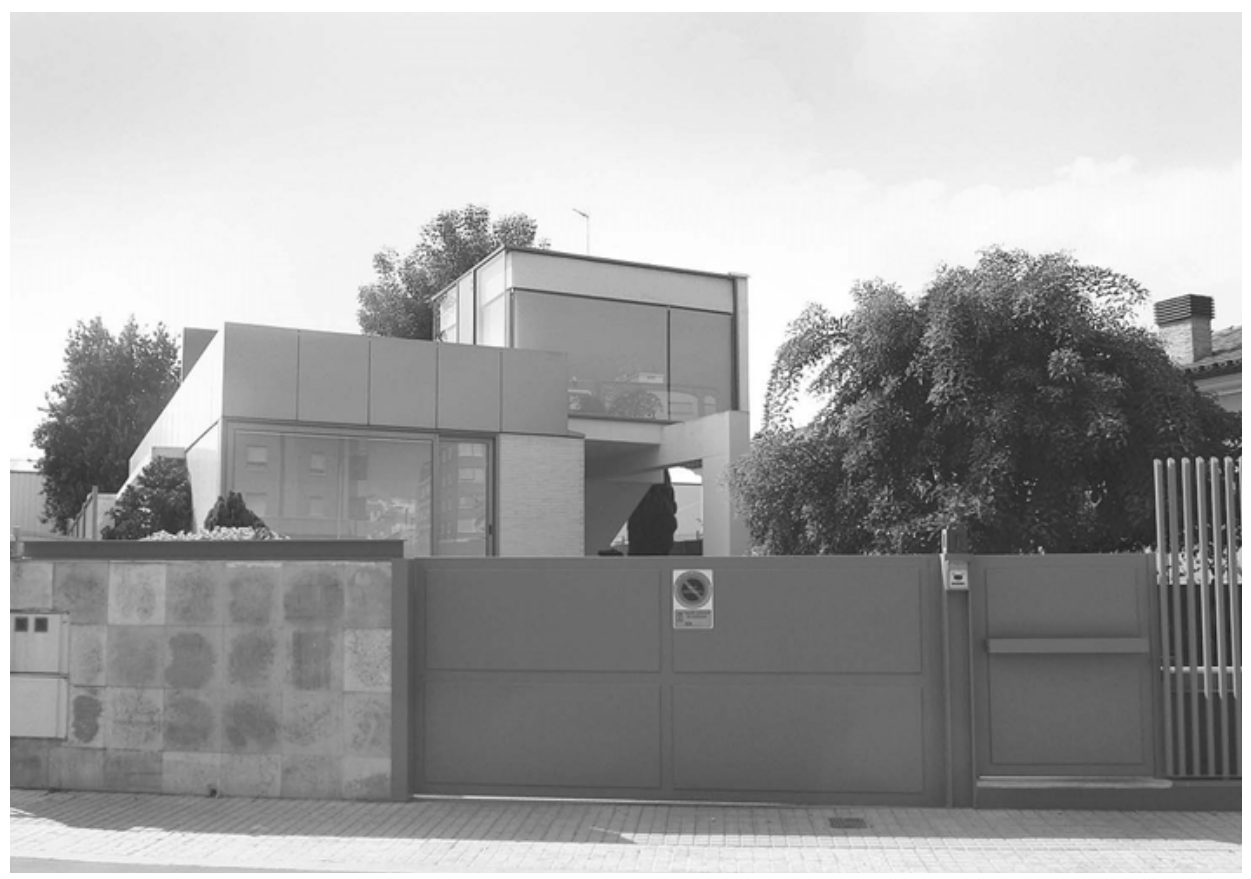

Habitatge unifamiliar situat al número 13 de l'avinguda de Jaume I (Foto: I. Cabrera).

Pel que fa als habitatges plurifamiliars, si acceptem les limitacions pressupostàries que els promotors solen imposar per a fer l'operació rendible, trobarem que durant aquest darrer quart de segle s'ha fet a Borriana una allau d'edificis que, en el millor dels casos, són intranscendents $i$, en el pitjor, autèntiques agressions al paisatge urbà carregades de pretensiositat. Tot i això, afortunadament també trobem exemples on els arquitectes han sabut combinar una adequada economia en una composició correcta i, en algunes ocasions, interessant. Mereixen menció els edificis situats al número 43 de l'avinguda de la Mediterrània, al número 2 del carrer de les Illes Columbretes, al número 8 de l'avinguda del Cardenal Tarancón i algunes promocions d'habitatges en filera de l'eixample del Grau.

\section{Mantindre, restaurar, renovar}

Tot i no ser l'única època de la qual preservem importants exemples, el final del segle XIX i principi del segle xx és, sens dubte, la més coneguda de totes i de la que mantenim el patrimoni arquitectònic més nombrós i conegut. La prosperitat del conreu i comerç de la taronja va omplir els nostres carrers amb una gran quantitat i varietat de construccions que llavors li van procurar un aspecte modern i avançat en comparació a la majoria de localitats veïnes (Goerlich, 1987: 347). Ben al contrari de com molts pensen, Borriana va generar un amplíssim patrimoni eclèctic, $\mathrm{i}$ els exemples modernistes són molt menys freqüents. Molts d'aqueixos edificis han arribat als nostres dies en bones condicions. Tot i això, la nostra història, pel que fa a la protecció del patrimoni arquitectònic, està plena de clarobscurs. 
La legislació nacional específica per al patrimoni historicoarquitectònic de 1933 va ser sistemàticament ignorada a Borriana. El deteriorament urbanístic, consentit per les autoritats locals, va arribar als anys setanta a tal nivell de gravetat ${ }^{21}$ que va ser el llavors Colegio Oficial de Arquitectos de Valencia y Murcia, amb unes altres entitats polítiques i culturals locals els qui van demanar la declaració de ciutat historicoartística per al municipi en 1978. Sorprenentment, el govern local es va oposar infructuosament a aquesta declaració. Adduïa que lesionava greument els interessos públics. La delegació de Castelló de l'Archivo Histórico del Colegio de Arquitectos va realitzar un llistat d'immobles que calia protegir que ascendia a 134 edificis, a més a més de sol-licitar la declaració com a parc natural del tram final del riu Anna.

Dos anys després i amb la Unió de Centre Democràtic al poder, el 6 de maig de 1980, el Ple de l'Ajuntament va adjudicar, previ concurs, a l'empresa PRODEIN, l'adaptació i revisió del Pla General d'Ordenació Urbana que, entre altres objectius concrets, havia de dotar de la necessària protecció als elements d'interès historicoarquitectònic i paisatgístic del terme municipal a través d'un catàleg. Però la concreció de mesures per protegir i conservar el patrimoni no arribaria fins al Pla General d'Ordenació Urbana de 1982, amb un catàleg que reduïa el llistat anterior a només 23 edificis (Català, 1991: 484). Tretze anys després, el Pla General de 1995 ampliava significativament el conjunt de béns arquitectònics, bàsicament de caràcter públic amb la incorporació de molts habitatges de propietat privada.

Molts exemples notables d'aquesta arquitectura residencial han arribat en condicions més que acceptables en l'actualitat. L'immoble situat al número 11 del carrer Major, tradicionalment conegut com «el Terròs», pel bar que hi havia ocupat la planta baixa, és ara un edifici d'habitatges. L'interior es va enderrocar i refer per complet, però les seues façanes, incloent-hi la del carrer de la Divina Pastora, han estat restaurades d'una manera magnífica. Al davant, al número 12, el Museu de la Taronja compleix ja fa més d'un any de tancament per falta de pagament i acord entre les administracions públiques. Tot i això, la façana de l'edifici encara reflecteix l'esplendor del moment de la construcció, a principis de segle xx, mentre que els interiors van ser absolutament renovats per a adequar-los a la funció de museu, a meitat dels anys noranta. Els patis i habitatges posteriors de la casa Reig, al número 17 de la Carrera, van ser enderrocats per a construir-hi el nou casino de la Caixa Rural Sant Josep, que aglutina també el vell palauet urbà de la secretària de March. Amb el nou projecte, s'ha perdut el magnífic mirador sobre el jardí, però s'ha assegurat la futura conservació de la resta d'elements incloent-hi l'excel-lent façana. Al número 1 del camí d'Onda, la casa del doctor Bernabé és avui seu de la Societat Club 53. Els llogaters mantenen l'edifici de manera acceptable i en 2013 n'han restaurat la façana.

Aquests i molts més exemples que cal agrair a iniciatives públiques, empresarials i d'una infinitud de propietaris anònims conscienciats, i sovint orgullosos, del valor del seu edifici, fan que Borriana preserve espais urbans amb un valor ambiental meravellós. Mereix obrir la relació d'espais més ressenyables el carrer de Sant Xuxim per l'elevat percentatge d'edificis que es mantenen com a principis de segle xx i la discreció dels nous. Valors arquitectònics

\footnotetext{
${ }^{21} \mathrm{~A}$ banda de les sistemàtiques agressions urbanístiques que va patir l'entorn de l'església parroquial del Salvador, l'exemple més flagrant i dissortat d'aquest deteriorament va ser l'enderrocament, en 1975, de la Casa Almela, paradigma del modernisme floral local, que havia estat situada al número 14 del carrer Major (Goerlich, 1987: 355).
} 


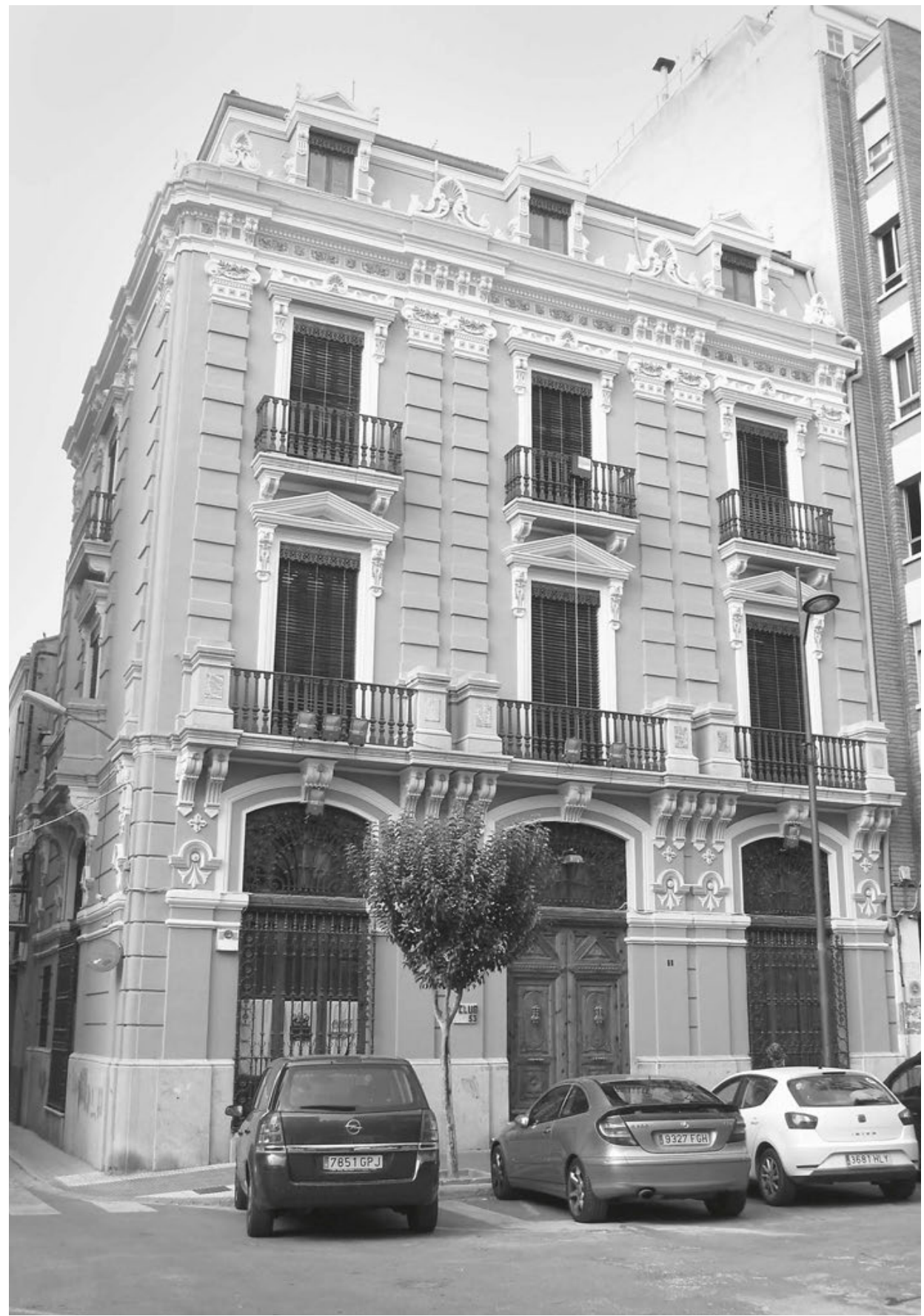

La casa Bernabé és la seu actual del Club 53 (Foto: I. Cabrera). 
ambientals semblants trobem a trams aillats del carrer Major, del carrer de la Puríssima i a tot el Barranquet, des del cantó amb el carrer de Sant Serapi fins al pla de Sant Blai. També resulta espectacular el conjunt format pel temple de Sant Josep, la casa Bernabé, el templet de la música i el quiosc del camí d'Onda, tot i que l'explotació hotelera d'aquest darrer element ha motivat la invasió d'una superfície excessiva amb una carpa i diversos tendals que desmereix totalment la bellesa d'aquest espai. Finalment, al districte marítim, el conjunt format pels quatre edificis que van des del número 87 al 91, presidit pel xalet de l'Ambaixador, encara dóna una idea fantàstica de les primeres construccions a la zona.

L'encís del terme encara es manté plenament en aquelles zones que no s'han vist alterades per les iniciatives urbanitzadores, tot i que la sort del patrimoni rural edificat ha estat heterogènia. Edificacions en mans privades i que encara estan en ús, com ara la torre de Calatrava o la recentment restaurada torre de Carabona, mostren un aspecte esplèndid. La resta llangueix en millor o pitjor estat en funció de la cura que els seus propietaris, o els seus fidels en el cas de les ermites, hagen tingut històricament amb l'edifici. Així doncs, el Palaciet, la torre del Mar o l'ermita de Santa Bàrbara presenten un aspecte acceptable, mentre que l'alqueria del Baró, la torre de Tadeo o l'ermita de la Sagrada Família amenacen severa ruïna si no reben una intervenció urgent.

La restauració més important duta a terme a Borriana els darrers anys ha estat, sens dubte, l'efectuada a l'església del Salvador amb motiu de la celebració de l'exposició de la Llum de les Imatges de 2008. El projecte de l'arquitecte Amando Llopis va continuar les tasques de restauració de l'absis que, anys enrere, havia dirigit Francisco Taberner, ${ }^{22}$ estenent-les per primera vegada des de la reconstrucció de després de la Guerra Civil a la nau barroca i a la capella de la Comunió. La lluminositat de l'espai interior i la riquesa policromàtica de les pintures de Vergara a les petxines de la cúpula van sorprendre tothom. Tot i això, tot el protagonisme se'l va endur el desitjadíssim, durant molts anys, enderrocament de la casa Abadia i conseqüent obertura de l'espai del fossar, obrint al gran públic, després d'infinitat d'anys, l'extradós de l'absis de la primera església de la reconquesta. El projecte d'adequació d'aquest espai, obra de l'estudi valencià «Vetges tu i Mediterrània», tot i la dificultat d'enfrontar-se amb un munt de façanes posteriors amb gran desordre volumètric, va aconseguir, amb el seu llenguatge modern i contundent, dignificar aquest espai. La renovació del fossar sempre tindrà el mèrit d'haver estat del gust de tothom, fins i tot dels més escèptics i conservadors, des del dia de la seua inauguració.

A més a més del fossar, altres espais urbans de la ciutat han renovat la imatge, però amb una mica més de controvèrsia. La renovació del carrer de Sant Vicent, projectada per l'arquitecte José Durán Fernández, ${ }^{23}$ ha estat certament el cas més polèmic. Amb policromia inspirada en les variades façanes del carrer, els grans i originals fanals han estat del gust de tothom. No és el cas del paviment, el disseny del qual, amb relleu excessiu, ${ }^{24}$ el fa

\footnotetext{
${ }^{22}$ Francisco Taberner Pastor és arquitecte i professor titular d'universitat del Departament d'Urbanisme de la UPV.

${ }^{23}$ José Durán Fernández és professor associat del Departament de Projectes Arquitectònics de la UPV.

${ }^{24}$ El projecte de renovació del carrer de Sant Vicent va coincidir amb l'entrada en vigor del Codi tècnic de l'edificació. L'apartat de la normativa dedicat a la seguretat d'utilització és tremendament sever pel que fa al lliscament dels paviments, circumstància que, òbviament, va influir José Durán a l'hora de dissenyar un paviment tan rugós.
} 


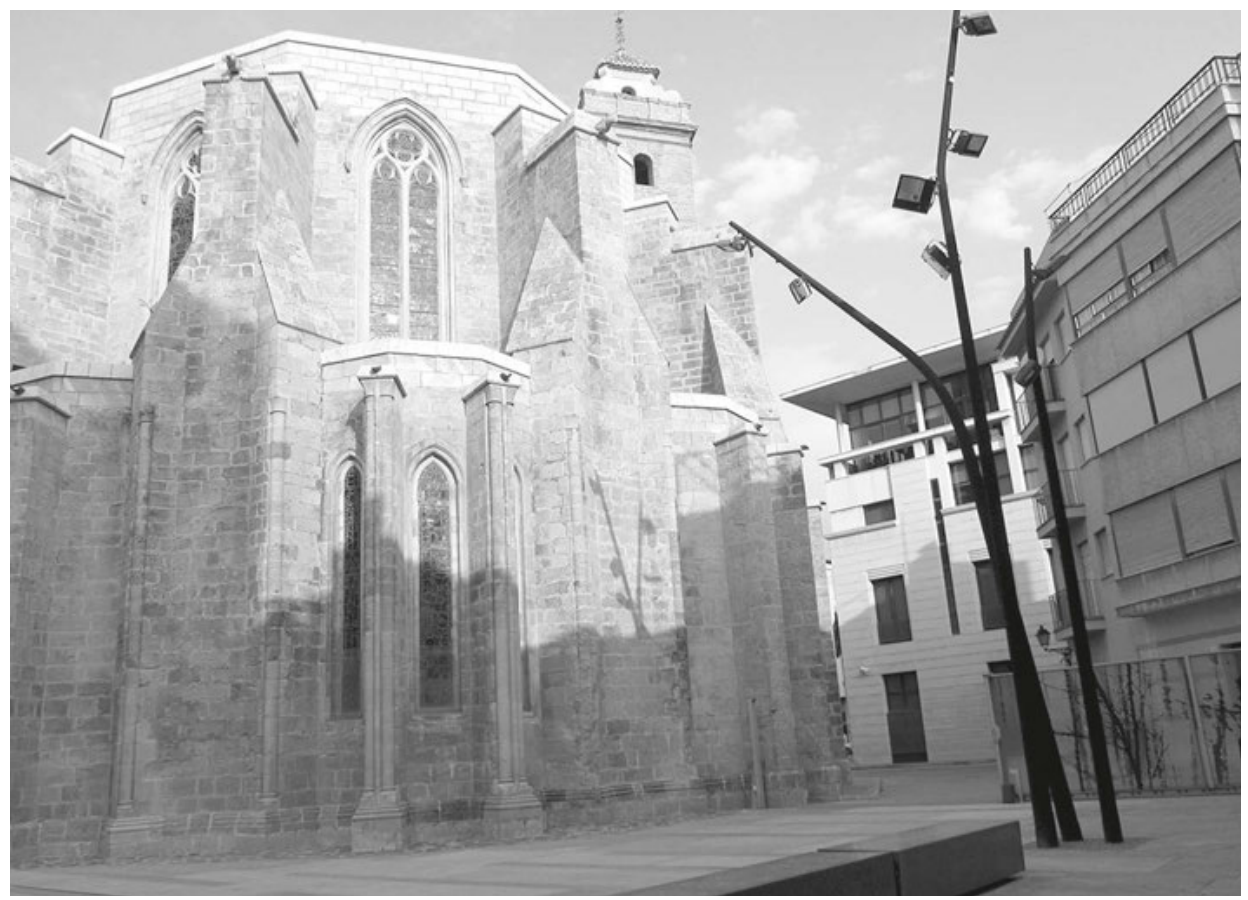

Vista exterior de l'absis de l'església del Salvador i de l'espai del fossar (Foto: I. Cabrera).

receptor inesgotable de qualsevol tipus de brutícia, i contínuament esmorteeix el color. Aquest deslluïment del terra i altres detalls menors li han generat un ampli col-lectiu de detractors. Mentrestant, el també ampli col-lectiu de defensors es mostra satisfet per l'atorgament del Premi Nacional d'Arquitectura en Ceràmica que va rebre en 2007. Del mateix autor, i igualment dissortat, és el projecte de renovació del carrer de Sant Pere Pasqual i de l'extrem nord de la plaça de la Mercè. En aquest cas, els forts moviments que va experimentar el gran fanal que presidia la intervenció van qüestionar-ne la viabilitat, al mateix temps que els camions que accedien a una obra veïna trencaven sistemàticament les peces d'un paviment que no estava concebut per a trànsit tan pesant.

En qualsevol cas, la contínua voluntat innovadora dels projectes de José Durán, amb èxit per a uns, desafortunats per a altres, els fa molt més interessants que altres intervencions com ara les renovacions del carrer de la Tanda o del carrer de Sant Marc, la intranscendència de les quals les manté fora de perill de les crítiques del gran públic. De fet, l'opinió pública borrianenca sempre ha estat molt més cruel amb les renovacions urbanes que no amb els edificis. Els mateixos que no tenen cap comentari per a alguns edificis públics absolutament infausts són els majors censors d'altres intervencions urbanes ben encertades com ara la renovació del Raval des del Pla fins al carrer de l'Ecce Homo.

Tot i l'activitat d'aquests darrers anys, Borriana encara té pendent la solució per un gran nombre d'espais urbans que juguen un paper cabdal en la percepció de la ciutat. 


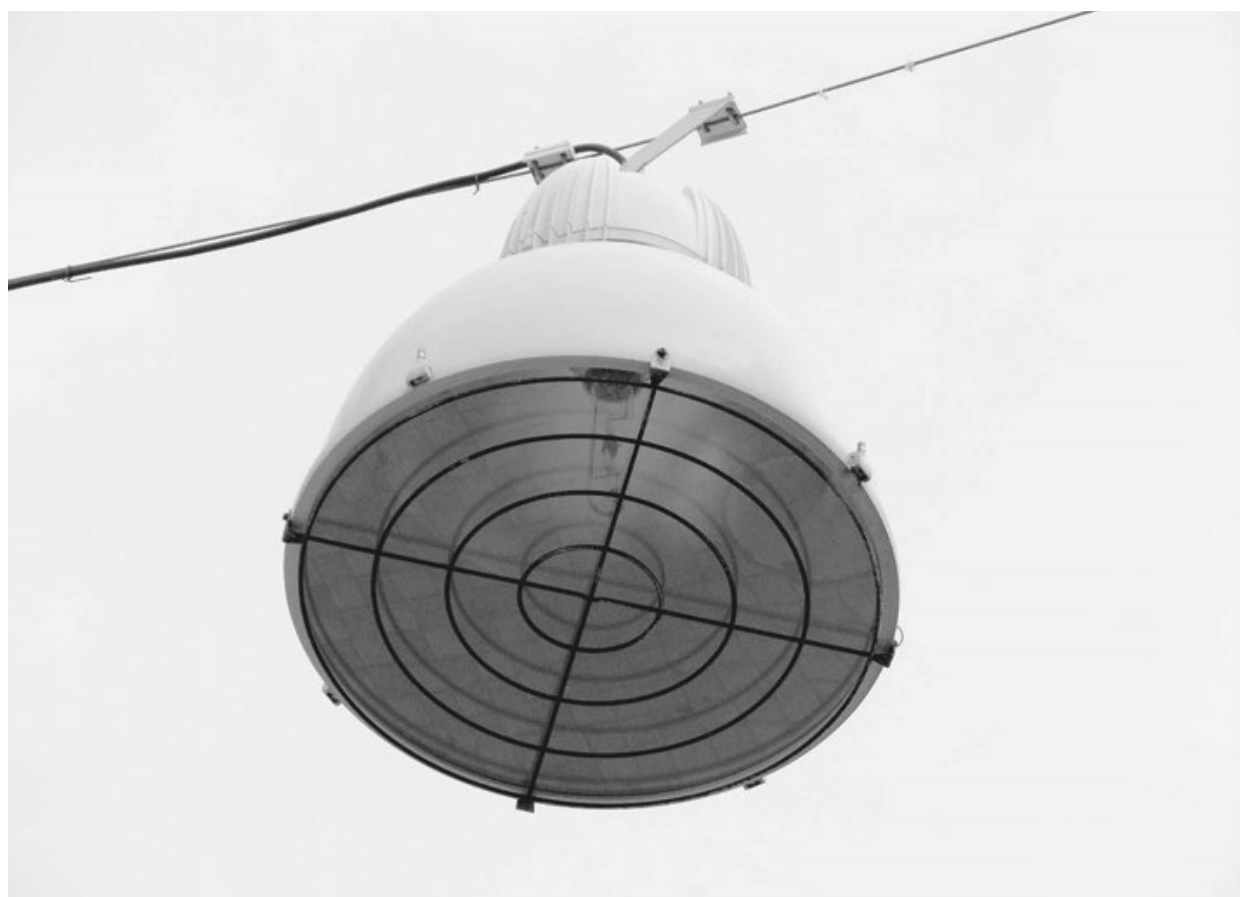

Nou fanal al carrer de Sant Vicent (Foto: I. Cabrera).

La reordenació del conjunt format per la plaça Major, els jardins i el Pla és l'exemple més obvi. Però resulta molt més urgent donar una solució a la terrassa Payà, un buit urbà ple de possibilitats que qualsevol ciutat desitjaria tindre al seu cor. El farcit d'aquest magnífic espai amb un volum edificat destinat a un ús tan profà com un aparcament o semblant suposaria un fracàs que encara s'és a temps d'evitar. De la mateixa manera, espera solució el conjunt format per la plaça del Mercat i la plaça d'Iturbi, la carretera del Port, la passejadíssima avinguda Mediterrània i, no cal dir-ho, els controvertits terrenys de l'Arenal.

\section{BIBLIOGRAFIA}

Benito Goerlich, D. (1987): «La arquitectura de 1890 a 1940», dins Mesado Oliver, N. (coord.): Burriana en su historia 1, Borriana, Magnífic Ajuntament de Borriana, 347-365.

Català Llop, B. (1991): «Historia del planeamiento urbanístico de Burriana», dins Mesado Oliver, N. (coord.): Burriana en su historia 1I, Borriana, Magnífic Ajuntament de Borriana, 477-490.

Instituto Nacional De Estadística (2013): <http://www.ine.es>.

Mesado Oliver, N. (1991): «Nuestro campo y su patrimonio cultural», dins Burriana en su historia Il, Borriana, Magnífic Ajuntament de Borriana, 153-231.

Torrent Fuertes, K. i E. Pla Vall (1987): «Evolución urbana», dins Mesado Oliver, N. (coord.): Burriana en su historia 1, Borriana, Magnífic Ajuntament de Borriana, 315-345.

— (1991): «Evolución de la población en la edad moderna», dins Mesado Oliver, N. (coord.): Burriana en su historia 1I, Borriana, Magnífic Ajuntament de Borriana, 275-298. 


\section{BIONOTES}

\section{Ivan Cabrera i Fausto}

(Borriana, 1974) Arquitecte per la Universitat Politècnica de València en 1998, és professor titular del Departament de Mecànica dels Medis Continus i Teoria d'Estructures de la mateixa universitat des de 1999 i cap d'estudis de l'Escola Tècnica Superior d'Arquitectura des de 2012. L'any 2010 va ser professor visitant a l'Illinois Institute of Technology de Chicago i en 2013 va rebre el Premi d'Excel-lència Docent del Consell Social de l'UPV i de la Conselleria d'Educació, Cultura i Esport de la Generalitat Valenciana. Actualment és membre del Consell de l'Associació Europea per l'Educació de l'Arquitectura. Coordina la seua tasca docent amb el treball com a arquitecte al seu estudi de Borriana.

\section{Ernesto Fenollosa Forner}

(Almenara, 1966) Arquitecte per la Universitat Politècnica de València en 1991 i doctor per la mateixa institució el 2010, és professor titular del Departament de Mecànica dels Medis Continus i Teoria d'Estructures d'aquesta universitat des de 1994 i coordinador acadèmic de tercer curs del títol d'Arquitecte des de 2002. Coordina la seua tasca docent amb el treball com a arquitecte al seu estudi de València, el qual comparteix amb Liliana Arguedas Reula. 